http://kitaibelia.unideb.hu/

ISSN 2064-4507 (Online) • ISSN 1219-9672 (Print)

(C) 2016, Department of Botany, University of Debrecen, Hungary

22 (1): 104-113.; 2017

DOI: $10.17542 /$ kit.22.104

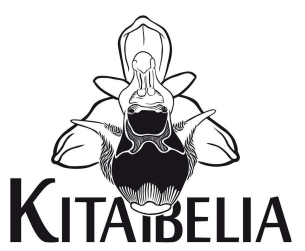

\title{
Adatok Magyarország flórájához és vegetációjához II.
}

\author{
ARADI Eszter ${ }^{1}$, ERDős László ${ }^{2}$, CSEH Viktória ${ }^{3}$, TÖLGYESI Csaba³ \& BÁTORI Zoltán
}

(1) Kiskunsági Nemzeti Park Igazgatóság, H-6000 Kecskemét, Liszt Ferenc utca 19.

(2) MTA Ökológiai Kutatóközpont Ökológiai és Botanikai Intézet, H-2163 Vácrátót, Alkotmány utca 2-4.

(3) Szegedi Tudományegyetem TTIK Ökológiai Tanszék, H-6726 Szeged, Közép fasor 52.; *zbatory@gmail.com

\section{Data to the flora and vegetation of Hungary II.}

\begin{abstract}
We report the occurrence data of 45 vascular plant taxa collected at various localities in Hungary (Duna-Tisza Interfluve, Tiszántúl and South Transdanubia) during floristic, vegetation and ecological field surveys mostly between 2013 and 2016. Many of these plants are included in the 'Red list of the vascular flora of Hungary' (e.g. Astragalus dasyanthus, Erodium ciconium and Lotus angustissimus). We primarily focused on the occurrence of rare plants (e.g. Apium repens, Epipactis bugacensis and Trifolium strictum), plants that appeared in unexpected places (e.g. Medicago arabica, Polypodium vulgare and Polystichum setiferum) or have a phyto-geographic importance (e.g. Piptatherum virescens, Ranunculus psilostachys and Tamus communis).
\end{abstract}

Keywords: alkaline habitats, Duna-Tisza Interfluve, secondary habitats, South Transdanubia, Tiszántúl

Összefoglalás - 45 taxon előfordulási adatait közöljük, melyeket nagyrészt a 2013-2016 közötti florisztikai, vegetációtani és ökológiai kutatásaink során találtunk. Adataink a Duna-Tisza köze, a Tiszántúl és a Dél-Dunántúl különböző élőhelyeiről származnak; a felsorolt fajok között számos szerepel a magyarországi edényes flóra veszélyeztetett fajainak listáján (pl. Astragalus dasyanthus, Erodium ciconium és Lotus angustissimus). Munkánkban törekedtünk a ritka (pl. Apium repens, Epipactis bugacensis és Trifolium strictum), a váratlan helyen megjelenő (pl. Medicago arabica, Polypodium vulgare és Polystichum setiferum), valamint a növényföldrajzi szempontból érdekesebb (pl. Piptatherum virescens, Ranunculus psilostachys és Tamus communis) taxonok adatainak közlésére.

Kulcsszavak: Dél-Dunántúl, Duna-Tisza köze, másodlagos élőhelyek, szikes élőhelyek, Tiszántúl

\section{Bevezetés}

Korábban megjelent tanulmányunkban (BÁTORI et al. 2014) Magyarország különböző tájairól (Dél-Dunántúl, Duna-Tisza köze és Tiszántúl) közültünk előfordulási adatokat ritka vagy különleges élőhelyen előforduló növényfajokról. Sok esetben cönológiai felvételt is készítettünk a fajok élőhely-preferenciájának alaposabb megismeréséhez. Jelen tanulmányban ugyanezeket a szempontokat tartottuk szem előtt: csak olyan fajok adatait közöljük, melyek ritkaságuk vagy váratlan helyen történő megjelenésük miatt lehetnek érdekesek.

A Maros menti területek természetközeli és másodlagos élőhelyeinek 2014 és 2015 közötti kutatása újabb eredményeket hozott. A terepi mintavételezések elsősorban a vonalas létesítmények (folyók töltései és vasúti töltések) növényzetére, valamint a szikes élőhelyek (cickórós puszták, szikes mocsarak és szikes rétek) növényzetére koncentrálódtak. 
A kiskunsági adatokat elsősorban ex lege védett lápterületek térképezése, valamint természetvédelmi hatósági eljárásokhoz kapcsolódóan végzett felmérések során gyűjtöttük.

A Dél-Dunántúlról származó adatok a Villányi-hegységben folyó élőhelytérképezési és társulástani kutatások során kerültek elő.

\section{Anyag és módszer}

Az előfordulási adatokat - az előző cikkhez hasonlóan - a nagyobb földrajzi egységeken belül (Dél-Dunántúl, Duna-Tisza köze és Tiszántúl) kistájakhoz rendeltük (KIRÁLY et al. 2008), az előfordulásoknál a településhatárokat is megadtuk. A dűlők megnevezésekor a turistatérképek (1:40000), az 1:25000 méretarányú katonai, valamint az 1:10000 arányú topográfiai térképek által használt neveket alkalmaztuk.

A taxonok sorszámozása és nevezéktana az Új magyar füvészkönyvet (KIRÁLY 2009) követi. Az előfordulási helyekhez tartozó CEU-kódok (KIRÁLY \& HORVÁTH 2000) szögletes, az észlelések évei kerek zárójelben szerepelnek.

A kistájak megnevezésénél az alábbi rövidítéseket alkalmaztuk:

\section{Duna-Tisza köze}

BH: Bugaci-homokhát

BLS: Bácskai löszös síkság

DMH: Dorozsma-Majsai-homokhát

DTV: Dél-Tisza-völgy

I: Illancs

KL: Kiskunsági-löszöshát

KS: Kalocsai-Sárköz
KH: Kiskunsági-homokhát

Ss: Solti-sík

Tiszántúl

MSz: Marosszög

Dél-Dunántúl

V: Villányi-hegység

\section{Enumeráció}

\section{Tiszántúl}

301. Cerastium glomeratum Thuill. - MSz: Deszk, Szeged (Újjzeged városrész): Utak mentén taposott, kaszált gyomvegetációban gyakori [9787.3, 9787.4] (2016). Az említett közösség néhány további gyakori faja: Bellis perennis, Convolvulus arvensis, Helminthia echioides, Leontodon hispidus, Lolium perenne, Poa annua, Polygonum aviculare, Setaria pumila, $S$. viridis, Veronica polita. BARTHA et al. (2015) nem jelzi a térség tágabb vonzáskörzetéből sem.

440. Ranunculus polyphyllus Waldst. et Kit. - MSz: Deszk: Szőregi-legelő, szikes mocsár és vízi harmatkákás átmeneti állományában, szórványosan; Parti-földek, szántók közé ékelődő, kis kiterjedésű szikes mocsárban, ritka [9787.3] (2014). Legközelebbi adatai a 30-40 km-re lévő Csanádpalota és Királyhegyes határából származnak (JAKAB 2012). A DélTiszántúlon szórványos (KERTÉsz 2000, JAKAB \& TóTH 2003, JAKAB 2005, BARTHA et al. 2015). Cönológiai felvétel a harmatkásás élőhelyről: Alopecurus pratensis +, Galium aparine +, Glyceria maxima 3, Iris pseudacorus 3, Lycopus exaltatus +, Lysimachia nummularia 1, Lythrum virgatum 1, Myosotis sicula +, Persicaria maculosa +, Ranunculus polyphyllus +, Rorippa austriaca +, Rumex crispus +, Schoenoplectus lacustris s.l. 1, Solanum sp. +, Symphytum officinale 1. Felvétel készítői: Bátori Zoltán, Cseh Viktória; hely: Deszk, szikes mocsár-vízi harmatkásás komplex; idő: 2014.05.26; mintaterület nagysága: 4 m²; gyepszint borítása: 75\%. Cönológiai felvétel a kis kiterjedésű szikes mocsárból: Agrostis stolonifera +, Alopecurus pratensis +, Bolboschoenus maritimus 5, Chenopodium sp. +, Juncus gerardii 1, Ranunculus polyphyllus +, Rorippa sylvestris +. Felvétel készítői: Bátori Zoltán, Cseh 
Viktória; hely: Deszk, szikes mocsár; idő: 2014.06.04; mintaterület nagysága: 4 m²; gyepszint borítása: $80 \%$.

954. Medicago arabica (L.) Huds. - MSz: Nagylak: a benzinkút degradált gyepjében [9890.1], kb. 0,25 m²-es folt (2014). Az Alföldön igen ritka, a Drávamenti-síkon és Szegeden adventív (KIRÁLY 2009, BARTHA et al. 2015). A közelében előforduló gyakoribb fajok: Arenaria serpyllifolia, Cerastium glomeratum, Elymus repens, Festuca pratensis, Geranium pusillum, Lamium amplexicaule, Lepidium draba, Myosotis stricta, Plantago lanceolata, Podospermum canum, Sclerochloa dura, Stellaria media, Taraxacum officinale, Trifolium repens.

964. Trifolium strictum L. - MSz: Deszk: a Szőregi-legelő szikes rétjein és cickórós pusztáin [9787.3, 9887.1], szórványos (2014). A Dél-Tiszántúl szikeseinek jellemző, de ritka faja (JAKAB 2012, BARTHA et al. 2015). Cönológiai felvétel szikes gyepből: Alopecurus pratensis 4, Bromus mollis + , Elymus repens 1, Inula britannica + , Limonium gmelinii subsp. hungaricum + , Lythrum sp. +, Plantago lanceolata 1, Poa pratensis s.l. 1, Sonchus asper +, Trifolium angulatum 2, Trifolium micranthum 1, Trifolium striatum + , Trifolium strictum 1. Felvétel készítői: Bátori Zoltán, Cseh Viktória; hely: Deszk, szikes rét; idő: 2014.05.26.; mintaterület nagysága: $4 \mathrm{~m}^{2}$; gyepszint borítása: 95\%. Cönológiai felvétel cickórós pusztából: Alopecurus pratensis + , Bromus mollis 1, Cerastium brachypetalum + , Cruciata pedemontana + , Elymus repens 1, Festuca pseudovina 5, Inula britannica 1, Limonium gmelinii subsp. hungaricum 2, Polygonum aviculare + , Trifolium micranthum + , Trifolium strictum + , Veronica arvensis + . Felvétel készítői: Bátori Zoltán, Cseh Viktória; hely: Deszk, cickórós puszta; idő: 2014.05.26; mintaterület nagysága: $4 \mathrm{~m}^{2}$; gyepszint borítása: 95\%.

986. Lotus angustissimus L. - MSz: Deszk: Szőregi-legelő, szikes réteken és cickórós pusztákon [9887.1], szórványos (2014). A Dél-Tiszántúl szikeseinek egyik jellemző faja; legközelebbi adata Hódmezővásárhely térségéből származik (JAKAB 2012, BARTHA et al. 2015). Cönológiai felvétel: Alopecurus pratensis 3, Bromus mollis + , Carex praecox + , Cirsium arvense + , Cruciata pedemontana 1, Cynodon dactylon 2, Festuca pseudovina 2, Gypsophyla muralis +, Inula britannica +, Lactuca saligna +, Lotus angustissimus 1, Myosotis sicula +, Plantago lanceolata 1, Poa pratensis s.l. 1, Potentilla argentea 1, Taraxacum officinale +, Veronica arvensis 3. Felvétel készítői: Bátori Zoltán, Cseh Viktória; hely: Deszk, cickórós puszta; idő: 2014.06.04.; mintaterület nagysága: $4 \mathrm{~m}^{2}$; gyepszint borítása: 80\%.

1025. Erodium ciconium (Jusl.) L'Hér. - MSz: Szeged: a Maros bal oldali töltésének délies kitettségű külső oldalán, a torkolathoz közeli szakaszon [9787.1, 9787.3], szórványos (2015). A Marosnak ez a töltésoldala igen száraz, a rajta található növényzet felnyíló, nyárra teljesen kiszáradó; fajösszetételét és szerkezetét tekintve kissé emlékeztet az egynyári homoki gyepekre. A Dél-Tiszántúlon szórványos faj (JAKAB 2005, BARTHA et al. 2015). A töltésen élő állomány közelében előforduló gyakoribb növények: Alyssum alyssoides, Bromus mollis, Calepina irregularis, Bromus tectorum, Carex praecox, Cerastium semidecandrum, Erodium cicutarium, Medicago minima, Poa bulbosa, Salvia nemorosa, Vicia angustifolia.

1175. Elatine alsinastrum L. - MSz: Deszk: Rigó-mező, szikes réten átfutó földút keréknyomában [9887.1], nedves talajon, ritka (2014). A Tisza és a Körösök egykori ártéri területeiről több előfordulása is ismert (DELI 2010, ЈАКАВ 2012). Cönológiai felvétel: Alisma lanceolatum 1, Alopecurus pratensis +, Beckmannia eruciformis 2, Elatine alsinastrum 1, Eleocharis palustris 2, Elymus repens + , Gypsophila muralis + , Lythrum hyssopifolia 2, Myosotis sicula 1, Myosurus minimus +, Peplis portula +, Polygonum aviculare 1, Potentilla supina +, Rorippa sylvestris +. Felvétel készítői: Bátori Zoltán, Cseh Viktória; hely: Deszk, földút keréknyoma; idő: 2014.06.04.; mintaterület nagysága: $50 \mathrm{~cm} \times 50 \mathrm{~cm}$; gyepszint borítása: $50 \%$.

1617. Linaria biebersteinii Besser - MSz: Deszk: Parti-földek, Szőregi-legelő, a Deszket Szőreggel összekötő vasútvonal töltésének mezsgyéjében [9787.3], kb. 100 tő (2015). JAKAB 
(2012) szerint leggyakrabban vonalas létesítmények mezsgyéiben találkozhatunk vele. A közelében előforduló gyakoribb fajok: Bromus mollis, Carduus acanthoides, Centaurea scabiosa s.l., Convolvulus arvensis, Elymus repens, Falcaria vulgaris, Festuca rupicola, Euphorbia salicifolia, Knautia arvensis, Lathyrus tuberosus, Papaver rhoeas, Phragmites australis, Poa pratensis s.l., Salvia nemorosa.

2175. Allium rotundum L. subsp. rotundum - MSz: Magyarcsanád: A Maros töltés déli kitettségű oldalán, Bökényhez és a Bekai-halomhoz közel [9890.1], száraz gyepben, kb. 70 virágzó tő (2015). Az Alföldön ritka (CSATHó 2009, KIRÁLY 2009); az új előfordulási hely a korábban (szintén a Maros töltéséről) közölt előfordulási helytől (BÁTORI et al. 2014) kb. 200 m-es távolságban található. A közelében előforduló gyakoribb fajok: Carduus acanthoides, Coronilla varia, Eryngium campestre, Festuca rupicola, Galium verum, Glycyrrhiza echinata, Phragmites australis, Salvia nemorosa, Torilis arvensis.

2184. Allium atropurpureum Waldst. et Kit. - MSz: Deszk: Parti-földek, Szőregi-legelő, a Deszket Szőreggel összekötő vasútvonal töltésének mezsgyéjében [9787.3], kb. 200 tő (2015). Békés és Csongrád megyében elsősorban gátakon és mezsgyéken fordul elő (JAKAB 2012, BÁTORI et al. 2014). A közelében előforduló gyakoribb fajok: Bromus mollis, Carduus acanthoides, Carex melanostachya, Centaurea scabiosa s.l., Coronilla varia, Crepis pulchra, Euphorbia salicifolia, Falcaria vulgaris, Festuca pseudovina, Festuca rupicola, Hypericum perforatum, Phragmites australis, Poa pratensis s.l., Salvia nemorosa.

2398. Aegilops cylindrica Host - MSz: Deszk: Rigó-mező, földút menti degradált, gyomos élőhelyen [9887.1], kb. $2 \mathrm{~m}^{2}$-es foltban (2014). A Dél-Tiszántúlon viszonylag gyakori (JAKAB 2012, BARTHA et al. 2015), a Maros töltésein is előfordul (BÁTORI et al. 2014). A közelében a következő fajokat találtuk: Alopecurus pratensis, Bromus arvensis, Bromus sterilis, Lolium perenne, Polygonum aviculare, Sclerochloa dura.

\section{Duna-Tisza köze}

26. Polypodium vulgare L. - BH: Kiskunmajsa és Tázlár között öreg fenyvesben, több kisebb telepet alkot [9483.4] (2016). Az aljnövényzetben előfordul még az Asplenium trichomanes és a Dryopteris filix-mas is. BARTHA et al. (2015) nem jelzi a Duna-Tisza közéről.

50. Polystichum setiferum (Forssk.) Woyn. - BH: Orgovány: a Kiskunsági Nemzeti Park Ágasegyházi-Orgoványi rétek területén egy homoki élőhely romos tanyahelyén, egy kútban 2 idős tövet és számos fiatal példányt találtunk [9282.2] (2015). A kutakban néhány tő Dryopteris filix-mas is található. BARTHA et al. (2015) a faj egyetlen nagyalföldi előfordulását sem jelzi.

93. Ephedra distachya L. - BH: Bugac: „bugaci ősborókás” [9383.2], a 2012-ben pusztító tűz által érintett területről, kiégett borókák tövéből került elő két foltban összesen pár 100 tő (2013). BARTHA et al. (2015) alapján a szomszédos [9383.1] kvadrátból van adata.

247. Corispermum marschallii Steven - KH: Izsák-Kisizsák: a két település között, fiatal fenyves telepítésben [9181.4], néhány 100 példány (2014). A hazai taxonokat érintő revízió óta nemigen ismert az egyes előforduló fajok elterjedése (BARTHA et al. 2015 sem közli a fajt), annyi azonban bizonyos, hogy a gyakori $C$. nitidum mellett igen ritkának tűnik mindhárom másik faj. A 2014 őszén tüzetesen megvizsgált állományok közül egyet találtunk, ami bizonyosan $C$. marschallii volt.

366. Dianthus superbus L. - BH: Kecel: a Nagy-Csukástól nyugatra, ex lege védett lápterületen [9481.1] több ezer tő (2015). Gymnadenia conopsea-val, Koeleria javorkae-val (lásd alább) egy gyepen, azonban állományaikat csatorna választja el. A buglyos szegfü élőhelye már-már sztyepprétté száradt, viszonylag fajszegény, egykori kékperjés láprét, melynek domináns fajai a Chrysopogon gryllus, Molinia caerulea, Briza media. A fajról számos adattal rendelkezünk a Kiskunságban, de a hasonló példányszámúak igen ritkák. Kecel, Csárda- 
lapos, a településtől, ill. a Kiskőrösre vezető 5301-es úttól északra a gyepvonulat középsőészaki részén [9481.1], kiszáradó kékperjés lápréten 300-500 tő (2015). A gyepvonulaton jelen van továbbá a Lathyrus palustris, Cirsium brachycephalum (mindkét fajból több ezer tő), Veratrum album, Orchis palustris, Gentiana pneumonanthe, Iris sibirica, valamint legdélebbi részén a Gymnadenia conopsea. BARTHA et al. (2015) a felsorolt védett fajok többségét jelzi ebből a kvadrátból, kivéve a buglyos szegfüvet és a szibériai nőszirmot.

443. Ranunculus lingua L. - KS: Baja-Érsekcsanád külterület-határon folyó Harábóicsatorna nádas medrében [9779.4], minimum néhány tucat tő (2014). BARTHA et al. (2015) szerint a térségből nincs adata a fajnak.

867. Astragalus dasyanthus Pall. - DMH: Ópusztaszer: Pitricsomi-legelő [9586.2], szikes mocsarak és szikes rétek közé ékelődő magaslat homoki sztyeprétjében, kb. 30 tő (2015). A populáció egyedeinek jelentős része nem minden bélyegében egyezik meg a legújabb határozóban (KIRÁLY 2009) használt bélyegekkel. A levél és a virágzat általában nem tőálló, a kocsány gyakran hosszabb $10 \mathrm{~cm}$-nél, a vitorla viszont majdnem minden esetben kopasz. Feltételezhetően az egyedek jelentős része az Astragalus dasyanthus-nak és az Astragalus exscapus-nak a hibridje (vö. FARKAS 1999). Az új populáció a 2010-ben a Pitricsomi-legelőn talált populációtól kb. 1,5 km-re található (BÁTORI et al. 2014). A közelében előforduló gyakoribb fajok: Centaurea scabiosa subsp. sadleriana, Chrysopogon gryllus, Dactylis glomerata, Dianthus pontederae, Festuca rupicola, Galium verum, Knautia arvensis, Medicago falcata, Phleum phleoides, Poa pratensis s.l., Rhinanthus serotinus, Salvia pratensis, Trifolium campestre.

1030. Linum flavum L. - I: Érsekhalma: az Érsekhalmi-völgy - a Savanyú-majorhoz vezető műúttal levágott déli végében [9680.2], viszonylag jó állapotú löszgyepen 150-200 tő (2009). A Kiskunságból BARTHA et al. (2015) szerint nincs adata a fajnak, de HoRVÁTH (2001) korábban megtalálta az ugyanehhez a CEU-kvadráthoz tartozó Érsekhalmivölgyben, annak északi részén, szálkaperjés xeromezofil gyepben.

1295. Apium repens (Jacq.) Lag. (Helosciadium repens [Jacq.] W.D.J. Koch) - KS: Császártöltés: a településtől délre, a jelenleg horgásztóként üzemelő, egykori tőzegbányatavak közelében, a Duna-völgyi főcsatorna és szántók közé ékelődő keskeny gyepsávon [9580.4], minimum százas nagyságrendben (2015). A területen a Duna-völgyi főcsatorna és a tavak közelsége ellenére könnyen megreked a víz, a növény megtalálása óta jellemzően 30-50 cm víz borította a területet, így a pontos állományméret meghatározására egyelőre nem volt lehetőségünk. 2014 elején Agrostis stolonifera dominálta mocsárrét-jellegű növényzet volt megfigyelhető, majd a vízszint emelkedésével szubdominánssá vált a Glyceria fluitans. Baja, a „Harábó” lápterület déli szegélyében, a 2010-ben előkerült állománytól (BÁTORI et al. 2014) légvonalban kb. 1600 méternyire [9779.4]. Időszakosan használt, gyakran víz alá kerülő földút növényzet nélküli nyomvályújában, 1-2 tucat tő (2014). Nemesnádudvar, a településbe nyugatról benyúló hibridnyaras által körülvett, mélyebben fekvő gyepfolton [9680.3], néhány ezer tő (2015). A térképek nem jelölnek forrást a területen, azonban a tulajdonos elmondása alapján a száraz években is rendszerint legalább tocsogós a talaj. A gyepet szarvasmarhával, viszonylag nagy intenzitással legeltetik. DMH: Kiskunhalas, Kertváros [9582.4], ingatlan előtti előkertben, nyírt gyepben, 100-200 tő (2015). Az előkertet 2-3 évvel ezelőtt újították meg, vélhetően az ehhez felhasznált tőzeggel kerülhetett be a növény. Sajnálatos módon nem sikerült kideríteni, hogy honnan származott a tőzeg, mindenesetre a nyírt, locsolt gyepben 20-30\% borításban van jelen a faj.

1363. Samolus valerandi L. - BH (KS határán): Kecel: a Berek-erdőhöz északnyugatról csatlakozó gyepnyúlványon [9481.1], minimum 100-150 tő (2015). A gyepvonulat közeli részein élő további védett fajok: Lathyrus palustris, Cirsium brachycephalum (mindkét fajból több ezer tő), Orchis palustris. BARTHA et al. (2015) egyetlen, 1951-1990 közötti archív adatát közli a Kiskunságból. 
1380. Blackstonia acuminata (W.D.J. Koch et Ziz) Domin - DMH: Balástya: a Digitaria ischaemum-mal (lásd alább) megegyező helyszínen, az előző cikkünkben (BÁTORI et al. 2014) jelzett magyar palkás homokbánya szegélyében [9585.4], több ezer tő (2014). Néhány tucat, esetleg 100-200 töves állományokról számos adatunk van a Duna-Tisza közéről, folyamatosan kerülnek elő újabb populációk, hasonlóan nagy példányszámú állományt azonban nemigen ismerünk a Kiskunságban. Jellemzően alacsonyra növő, aligalig elágazó példányok nőnek a bányászat óta szikesedő területen; ennek oka lehet, hogy 2014-ig időszakosan, de viszonylag nagy gyakorisággal birkákat hajtottak át a területen. Tipikus kísérőfajai ekkor a Gnaphalium luteoalbum, Centaurium pulchellum, C. erythraea, Calamagrostis epigeios (foltokban tömeges), Agrostis stolonifera voltak, a növényzet záródása 50-80\% között mozgott. 2015-ben a legeltetés elmaradt, és már az egy évnyi kezeletlenség is a növényzet gyors ütemű záródásához vezetett, előretört a Calamagrostis epigeios. BARTHA et al. (2015) szerint a legközelebbi előfordulásai a [9584.2] és a [9685.4] kvadrátokban. DTV: Sándorfalva, honvédségi lőtér [9586.4], több ezres állomány, nagyrészt nyíltabb (növényzeti összborítás 20-50\%) homokfelszínen (2010). A Cyperus flavescens (BÁTORI et al. 2014) közelében. BARTHA et al. (2015) nem jelzi az adott kvadrátban.

1606. Scrophularia umbrosa Dumort. - KS: Császártöltés: a településtől nyugatra, csatorna menti, erőteljesen nádasodó, illetve aranyvesszővel foltokban erősen fertőzött magassásosban [9580.4], néhány tucat példány (2014). A Kiskunsági Nemzeti Park Igazgatóság működési területéről Lakitelek-Tőserdőről volt ismert korábban (BoRos 1961-es publikálatlan útinaplója, BP: SzUJKó-LACZA 1983), valamint 2011-ben került elő néhány töve Sükösd külterületén (BÁTORI et al. 2014). Két további aktuális előfordulást jelöl BARTHA et al. (2015): a kiskőrösi Őrjeg vonulatáról, és az izsáki Kolon-tó környezetéből.

1670. Odontites Iutea (L.) Clair. - DMH: Zsana: a településtől alig 1 kilométernyire nyugatra, mezőgazdasági telephelyhez vezető földút mentén, néhány sor széles, ritkás lombkoronájú hibridnyaras alatt [9683.2], 1000-1500 tő (2014). A faj a Duna-Tisza közén ritka, BARTHA et al. (2015) összesen 8 CEU kvadrátból jelzi (jelen előforduláshoz a legközelebbi a szomszédos [9683.1]), hasonlóan nagy méretű állományról aktuális adattal a Kiskunságból nem rendelkezünk.

2138. Triglochin palustris L. - KH: (Izsák-)Kisizsák DK-i csücske és a kisizsáki (II.) összekötő-csatorna között [9181.4], jó vízellátottságú, tarackos tippanos gyepen, néhány tucat tő (2014). KS: Sükösd, a településtől ÉK-re, a nemesnádudvari külterület határon, (nagyrészt) felhagyott tőzegbányatavak láncolatának keleti felében épen maradt gyepfolton [9680.3], magassásos növényzetben, néhány tucat tő (2011). BARTHA et al. (2015) egyetlen adatot sem jelöl a fajra a Kiskunságból.

2195. Polygonatum Iatifolium (Jacq.) Desf. - I: Kéleshalom: Kéleshalmi Homokbuckák TT [9682.1], cserjés foltban. A Duna-Tisza közén szórványos, a közelben Kunfehértóról, Kiskunhalasról és Soltvadkertről jelezték előfordulását (SzUJKó-LACZA \& KovÁTS 1993).

2246. Tamus communis L. - BLS: Vaskút: a településtől nyugatra-délnyugatra [9879.4], 2025 éves, a cserjeszintben még nem záródott Celtis occidentalis-os, szürke nyárral elegyes akácos alatt, egy idős tő. Előfordulásának eredete kétséges. BARTHA et al. (2015) egyetlen Duna-Tisza-közi adatként, (vélhetően) Hercegszántó külterületéről, kb. 22-24 kilométernyi távolságból jelzi a fajt.

2432. Koeleria javorkae Ujhelyi - BH: (Illancshoz, Kalocsai Sárközhöz egyaránt közel): Kecel, a kiskőrösi határban, a Köleséri-dűlőben, szőlők szegélyében húzódó ex lege védett lápterületen [9481.2] (2015). A bejárás során a gyep jelentős része frissen kaszált állapotban volt, így megközelítőleg sem állapítható meg a példányszám. A gyepvonulaton jelen van a Gymnadenia conopsea, Orchis palustris, O. coriophora. KS: Kecel, a Nagy-Csukástól nyugatra, ex lege védett lápterületen [9481.1], ahol a leszáradófélben lévő gyepen a kékperje mel- 
lett gyakori a Holchus lanatus, Deschampsia caespitosa is, néhány 100 tő (2015). A gyep további védett fajai: Dactylorhiza incarnata, Gymnadenia conopsea, Orchis palustris, $O$. coriophora, Gentiana pneumonanthe, Iris sibirica, Dianthus superbus (lásd fenn). Ss: Akasztó, a településtől északra, ex lege védett lápterületen [9281.3], néhány 100 tő (2015). KL: Tiszaalpár-Kiskunfélegyháza külterület határon, Tiszaalpártól délre, a Nagy-Sóstó nevű ex lege védett szikes tó nyugati szegélyében [9285.2], ahol keskeny sávban lápi jellegű növényzet jelenik meg, Molinia caerulea-val, Sanguisorba officinalis-al, Iris sibirica-val. Az állomány mérete kicsi, alig 1-2 tucat tő (2015).

Sem SzUjKó-LACZA \& KovÁTS (1993), sem FARKAS (1999) nem jelzi egyik fenn szereplő külterületről sem, míg BARTHA et al. (2015) a K. cristata-val összevontan közli a fajt, így nem nyerhető ki adat az előfordulásáról.

2472. Piptatherum virescens (Trin.) Bioss. - BH: Fülöpháza község külterületén, a Kiskunsági Nemzeti Park Fülöpházi homokbuckák területén, egy öreg, inváziós fajokkal fertőzött fenyvesben találtunk rá egy néhány négyzetméteres állományára (9182.1) (2016). Az állomány közvetlen közelében előforduló egyéb fajok: Ailanthus altissima, Amorpha fruticosa, Asclepias syriaca, Asparagus officinalis, Astragalus austriacus, Berberis vulgaris, Conyza canadensis, Gleditsia triacanthos, Euphorbia seguieriana, Juglans regia, Lithospermum officinale, Morus alba, Robinia pseudoacacia, Taraxacum officinale és Viola rupestris. A faj a Nagyalföldön egyedül a Mezőföld egy-egy pontján fordul elő (KIRÁLY 2009, BARTHA et al. 2015). Jelen előfordulásának természetes volta kétséges, lehetséges, hogy erdészeti szaporítóanyaggal érkezett.

2509. Digitaria ischaemum Schreb. Ex Muhl. - DMH: Balástya: a csólyospálosi külterületi határ közelében, a Balástya-Csólyosi csatornától északra, a Bitó-szék szikes tómedrétől délre [9585.4], néhány 100 tő (2014). A lelőhelyen korábbi szántó helyén kialakított, majd 2010-ben felhagyott homokbánya található, amelyet részben talajvízszintig, részben csupán kb. 0,5-1 méternyi mélységig bányásztak. Az erőteljesebben kimélyített területeken a homokpadok magasságától függően időszakos/állandó vízborítás figyelhető meg, a nyár közepére-végére szárazra kerülő magaslatokon 2013-ban került elő a Cyperus pannonicus (BÁTORI et al. 2014), míg a kis mértékben elbányászott felszíneken 2014-ben észleltük a gyíkpoharat (lásd fent), és az apró ujjasmuhart. A faj a Duna-Tisza-közén kifejezetten ritka, BARTHA et al. (2015) mindössze néhány kvadrátból jelzi, a legközelebbi kettő a 9485.3 és a 9587.3 (ez utóbbi akár Tiszántúli előfordulás is lehet). KIRÁLY (2009) szerint mészkerülő fajról van szó, azonban a talaj az adott területen bizonyosan meszes, a bányászat óta másodlagosan szikesedik.

2578. Cyperus flavescens L. - KS: Nemesnádudvar: a településtől keletre a forráslápon [9680.3], néhány tő (2014). A terület ex lege védett láp, egyike a Kiskunság területén még múködő kisszámú forráslápoknak. A lelőhely megegyezik a korábbi cikkünkben (BÁTORI et al. 2014) jelzett Apium repens lelőhelyével. A terület talaja az extrém aszályos időjárású években is rendszerint egész évben víztelített, tocsogós. A láp szarvasmarhával erősen legeltetett, 2014 őszén helyenként elérte az 50\%-ot a nyílt talajfelszín aránya; ilyen területen jelent meg a palka is. BARTHA et al. (2015) az adott kvadrátból nem jelzi sem ezt a fajt, sem a forráslápon mellette előforduló következő fajokat: Eriophorum latifolium, Triglochin palustris, Menyanthes trifoliata.

2604. Carex appropinquata Schumach. - BH: Ágasegyháza határában, a Kiskunsági Nemzeti Park Ágasegyházi-Orgoványi rétek területén két elkülönült foltban 23 [9183.3] és 2 [9182.4] zsombék került elő láposodó mélyedésben (2016). Az első élőhely egy rekettyefúzes nádas, mely azonban a területtel nyugati irányban érintkező szántott hát intenzív mütrágyázása miatt degradációnak indult, jelenleg a fekete bodza (Sambucus nigra) és a nagy csalán (Urtica dioica) tömeges felszaporodása tapasztalható. A másik élőhely egy erősen becserjésedett (főleg Frangula alnus és Crataegus monogyna) vályogvető gödör lehetett, 
jelenleg a faj a teljesen zárt cserjeszint alatt tengődik. Mindkét élőhely esetén tehát aktív természetvédelmi beavatkozásra van szükség, különben a faj hamarosan eltűnik a területről. A nemzeti park e területéről nem volt ismert a faj korábbról (BARTHA et al. 2015). A legközelebbi ismert állományok a Fülöpszállás-Soltszentimre-Csengődi lápok Natura 2000 területen találhatók.

2667. Epipactis bugacensis Robatsch - KL: Tiszaalpár: a településtől délre, a CsongrádKiskunfélegyháza hármashatár közelében, foltokban felnyíló, 80-90\%-os lombkoronazáródású, idősebb hibridnyarasban [9285.4], ezres nagyságrendben, E. atrorubens-el együtt (2015). A térségből egyik fajt sem ismertük korábban, azonban BARTHA et al. (2015) mindkettőt jelzi a szomszédos [9285.2] kvadrátból. A nyaras aljnövényzetében konstansan jelen van az Asclepias syriaca, azonban ahol borítása nem haladja meg a 40-50\%-ot, megél mellette a nőszőfü is.

2677. Cephalanthera longifolia (L.) Fritsch - DMH: Ásotthalom: Emlékerdő [9784.4], fehérnyárasban (2014). A Duna-Tisza közén szórványos (FARKAS 1999), az Emlékerdő területéről korábban nem került elő (vö. BoDROGKÖZY 1957, SzUJKó-LACZA \& KovÁTS 1993, GASKó 2009).

2681. Listera (Neottia) ovata (L.) R. Br. - Ss (a KH határán): Akasztó településtől északra, a Bikatori-szőlőktől nyugatra-északnyugatra, ex lege védett lápterület keleti szegélyében [9281.3], kisebb (részben zöld juharos) facsoport alatt, szedres-kékperjés növényzetben 200-300 tő (2015). BARTHA et al. (2015) a [9281.4] kvadrátból 1950 előttről származó archív adatot, míg a [9282.3]-ból, és a [9381.2]-ből aktuális előfordulást közöl. (2015). BLS: Vaskút, a település szegélyétől kb. 300 méterre nyugatra-délnyugatra [9979.2 északi szegélye], szegényes, jellegtelen aljnövényzetű, selyemkóróval gyengén-közepesen fertőzött akác-szürkenyaras elegyben, minimum 100-150 tő. Szórványosan Cephalanthera longifolia is jelen van az erdőben. BARTHA et al. (2015) egyik fajt sem jelzi az adott kvadrátból.

2702. Orchis (Neotinea) tridentata Scop. - KL: Kecskemét: Csalánosi-Parkerdő keleti fele [9183.2], tisztás szegélyén egy tő (2015). Aktuális előfordulási adatával ezen kívül nem rendelkezünk. SzUjKó-LACZA \& KovÁTS (1993) a 19. sz. végéről - 20. sz. elejéről jelzi Kecskemét mellől, a Nyírből, illetve Kalotás Zsolt szóbeli közlése alapján Miklapusztán virágzott egy tő az 1990-es években.

\section{Villányi-hegység}

34. Asplenium javorkeanum Vida - Villány: Somsich-hegy, részben honos fajok, részben gyümölcsfák által alkotott rontott cserjésben [0176.2], egyetlen tő (2016). Ugyanezen a helyen TOLNAY (2016) is megtalálta. A Villányi-hegységben korábban a Szársomlyóról (Kitaibel P. in HoRvát 1942, Vöröss 1966, MolnáR et al. 1970, DÉNES 1998), a Tenkesről (VISNYA A. in HORVÁt 1936), a Templom-hegyről (PAPP J. in HoRVÁt 1957, SOMLYAY 2000), a Fekete-hegyről (BÁTORI et al. 2010) és Villánykövesdről (NAGY 1959, ERDős et al. 2011) jelezték.

438. Ranunculus psilostachys Griseb. - V: Villány: Kálvária-domb [0176.2], nyírt gyepben (2015). A Villányi-hegységben szórványos előfordulású, a legközelebbi ismert termőhelye a Szőlőhegyen van (BÁTORI et al. 2014).

--- Sedum sarmentosum Bunge - V: Villány: szőlőhegy, a település közvetlen közelében [0176.2], sekély talajú útszéli gyomnövényzetben, egy kis foltban (2014). A Villányihegységből korábbi munkák (DÉNES 2000, KEVEY \& HORVÁT 2000) nem jelezték kivadulását.

1070. Dictamnus albus L. - V: Csarnóta-Harkány: Kis-hegy [0175.1], cserjésedő sziklagyepben, kb. 40 tő (2014). A Villányi-hegységben viszonylag gyakori, de a Kis-hegyről korábban nem került elő; legközelebbi ismert előfordulása a szomszédos Nagy-hegyen és a Tenkesen van (ERDős et al. 2011). 
1085. Acer campestre L. - V: Hegyszentmárton: az északi hegylábnál [0174.2], legelő szélén (2014). A tekintélyes méretű fákból álló csoportból kettő példány a faj legnagyobb termetű egyedei közé tartozik Magyarországon (mellmagassági törzskerületük: 375 és $378 \mathrm{~cm}$ ). A fák alatt az eredeti gyertyános-tölgyes aljnövényzete maradt fenn, többek között Galanthus nivalis, Isopyrum thalictroides, Anemone ranunculoides, Galeobdolon montanum, Corydalis cava, Aegopodium podagraria, Ranunculus ficaria, Pulmonaria officinalis, Stachys sylvatica, Stellaria holostea, Geranium phaeum, Polygonatum latifolium, Viola reichenbachiana.

1461. Phacelia tanacetifolia Benth. - V: Villány: Szőlőhegy, szőlősorok közti gyomnövényzetben [0176.2], tömeges (2014). Villányból utoljára HoRvÁt (1977) említette.

2195. Polygonatum latifolium (Jacq.) Desf. - V: Diósviszló: Felső-erdő [0174.2], akácos szélén (2014). A Villányi-hegységben ritka (ERDős et al. 2011), a közelben eddig nem volt ismert.

2463. Alopecurus pratensis L. - V: Diósviszló: Felső-erdő [0174.2], erdőszéli úton (2014). A Villányi-hegységben viszonylag ritka, előfordulásai főként a hegylábi területeken vannak.

\section{Adatközlők}

Tiszántúl: 301: TCs; 440: BZ, CsV; 954: BZ; 964: BZ, CsV; 986: BZ, CsV; 1025: BZ; 1175: BZ, CsV; 1617: BZ, CsV; 2175: BZ, CsV; 2184: BZ, CsV; 2398: BZ, CsV. Duna-Tisza köze: 26: TCs; 50: TCs; 93: AE; 247: AE; 366: AE; 443: SA; 867: BZ; 1030: AE-MA-BZs; 1295: Császártöltés: AE, Érsekcsanád: SA, Nemesnádudvar: TÁ, Kiskunhalas: KT; 1363: AE; 1380: Balástya: AE, Sándorfalva: AE-TL-PuJ; 1606: AE; 1670: AE; 2138: AE; 2195: EL, BZ, TCS; 2246: PJ; 2432: AE; 2472: TCs; 2509: AE; 2578: AE; 2604: TCs; 2667: AE; 2677: EL; 2681: Akasztó: AE, Vaskút: PJ; 2702: BCs (det.: VZ-KÉ-AE). Villányi-hegység: 34: EL; 438: EL; Sedum sarmentosum: EL; 1070: EL; 1085: EL; 1461: EL; 2195: EL; 2463: EL

\author{
AE: Aradi Eszter \\ BZs: Barna Zsolt \\ BCs: Bán Csaba \\ BZ: Bátori Zoltán \\ CsV: Cseh Viktória
}

\author{
EL: Erdős László \\ KÉ: Kovács Éva \\ KT: Kiss Tamás \\ MA: Máté András \\ PJ: Pillinger János \\ PuJ: Puskás József
}

\author{
SA: Sirok Attila \\ TÁ: Tamás Ádám \\ TCs: Tölgyesi Csaba \\ TL: Tajti László \\ VZ: Vajda Zoltán
}

\section{Köszönetnyilvánítás}

Köszönetünket szeretnénk kifejezni adataik átadásáért és a terepmunkában nyújtott segítségért Kiss Tamásnak (Kiskunhalas), Pillinger Jánosnak (Vaskút), Sirok Attilának (Kecskemét), valamint a KNPI munkatársainak: Tamás Ádámnak, Sipos Ferencnek és Bán Csabának. Erdős László munkáját az OTKA (PD 116114) támogatása tette lehetővé.

\section{Irodalom}

Bartha D., Király G., Schmidt D., Tiborcz V., Barina Z., Csiky J., Jakab G., Lesku B., Schmotzer A., Vidéki R., Vojткó A. \& ZóLYomi Sz. (szerk.) (2015): Magyarország edényes növényfajainak elterjedési atlasza. Nyugat-magyarországi Egyetem Kiadó, Sopron, 329 pp.

BátoRi Z., Bock Cs. \& ERDős L. (2010): Florisztikai adatok a Dél-Dunántúlról. - Kitaibelia 15: 95-100.

BÁtori Z., ERdôs L., CSEH V., TölgYesi Cs. \& ARADi E. (2014): Adatok Magyarország flórájához és vegetációjához I. - Kitaibelia 19: 89-104. 
BodRoGKÖZY Gy. (1957): Die Vegetation der Weisspappel-Haine in dem Reservat „Emlékerdő” bei Szeged-Ásotthalom. - Acta Biologica Szegediensis 3: 127-140.

CsATHó A. I. (2009): A mezsgyék természetvédelmi jelentősége és védelmük időszerűsége. Természetvédelmi Közlemények 15: 171-181.

DELI T. (2010): Adatok Békés megye iszapgyom flórájához. - Gyomaendrőd környékének iszapgyomjai. - Crisicum 6: 59-78.

DÉNES A. (1998): A Villányi-hegység Chrysopogono-Festucion dalmaticae társulásai. - In: CsonTos P. (szerk.), Sziklagyepek szünbotanikai kutatása. Scientia Kiadó, Budapest, pp. 57-76.

DÉNES A. (2000): A Villányi-hegység flóra- és vegetációkutatásának története, eredményeinek összefoglalása, különös tekintettel a védett és ritka fajok előfordulására. Dunántúli Dolgozatok Természettudományi Sorozat 10: 47-77.

ERDôs L., Tolnay D. \& TóTH V. (2011): Kiegészítések a Villányi-hegység flórájához. - Botanikai Közlemények 98: 117-128.

ERdôs L., Tolnay D., Tóth V. (2011): Kiegészítések a Villányi-hegység flórájához. - Botanikai Közlemények 98: 117-128.

FARKAS S. (szerk.) (1999): Magyarország védett növényei. - Mezőgazda Kiadó, Budapest, 416 pp.

GASKó B. (2009): Csongrád megye természetes és természetközeli élőhelyeinek védelméről II. - Studia Naturalia 5: 1-486.

Horvát A. O. (1936): Analysis florae comitatus Baranya. - Ex flora Baranyaënsi 2. - A Pécsi Városi Múzeum Kiadványai 4: 3-20.

Horvát A. O. (1942): Képek a Mecsek növényéletéből. - A Ciszterci Rend kiadása, Pécs, 104 pp.

HoRvát A. 0. (1957): Pótadatok a Mecsek hegység és környékének flórájához. - A Janus Pannonius Múzeum Évkönyve 2: 163-180.

HorvÁt A. O. (1977): Pótlások és kiegészítések „A Mecsek-hegység és déli síkjának növényzete” ismeretéhez II. - A Janus Pannonius Múzeum Évkönyve 19: 37-56.

Horváth A. (2001): A Bácskai löszös hátság Császártöltés - Sükösd közötti területének botanikai felmérése és vegetációtérképezése - Kutatási jelentés a KNPI részére, 76 pp.

JAKAB G. \& TóTH T. (2003): Adatok a Dél-Tiszántúl flórájának ismeretéhez. - Kitaibelia 8 (1): 89-98.

JАКАВ G. (2005): Adatok a Dél-Tiszántúl flórájának ismeretéhez II. - Flora Pannonica 3: 91-119.

JAKAB G. (szerk.) (2012): A Körös-Maros Nemzeti Park növényvilága. - Körös-Maros Nemzeti Park Igazgatóság, Szarvas, 413 pp.

KERTÉSz É. (2000): Adatok a Dél-Tiszántúl flórájához. - A Békés Megyei Múzeumok Közleményei 21: 5-48.

Kevey B. \& Horvát A. O. (2000): Pótlások és kiegészítések „A Mecsek-hegység és déli síkjának növényzete” ismeretéhez (1972-2000). - Folia Comloensis 9: 5-70.

KiRÁlY G. (szerk.) (2009): Új Magyar Füvészkönyv. Magyarország hajtásos növényei. Határozókulcsok. Aggteleki Nemzeti Park Igazgatóság, Jósvafó, 616 pp.

KiRÁlY G. \& HoRVÁTH F. (2000): Magyarország flórájának térképezése: lehetőségek a térképezés hálórendszerének megválasztására. - Kitaibelia 5 (2): 357-368.

KIRÁLY G., MolNÁR Zs., BöLÖNI J., CSIKY J. \& VojTKó A. (szerk.) (2008): Magyarország földrajzi kistájainak növényzete. - MTA ÖBKI, Vácrátót, 248 pp.

MoLNÁR P., VÁRKONYI T. \& VöRöss L. Zs. (1970): A levegőszennyeződés hatása a Szársomlyó növényzetére. - MTESZ Tanulmányok 3: 17-29.

NAGY I. (1959): Adatok Villány és környéke flórájához. - Botanikai Közlemények 48: 100.

SOMLYAY L. (2000): Adatok a Villányi-hegység és környéke flórájához, különös tekintettel a gyomokra. Dunántúli Dolgozatok Természettudományi Sorozat 10: 79-88.

SzujKó-Lacza J. \& KováTs D. (szerk.) (1993): The flora of the Kiskunság National Park I. - Magyar Természettudományi Múzeum, Budapest, 465 pp.

TolnAY D. (2016): A villányi Somsich-hegy természeti értékei, a veszélyeztető tényezők és természetvédelmi teendők. - Kitaibelia 21: 55-62.

VöRöss L. Zs. (1966): A Ranunculus psilostachys Griseb. társulási viszonyai. - Botanikai Közlemények 53: 165-170.

Beérkezett: 2017. 02. 28. • Elfogadva: 2017. 03. 16. 